Article

\title{
Feeding Behavior of Lactating Dairy Cattle Fed Sorghum-Based Diets and Increasing Levels of Tannic Acid
}

\author{
José Danrley Cavalcante dos Santos ${ }^{1,2}$, Edilson Paes Saraiva $2,3, * \mathbb{B}$, Severino Gonzaga Neto ${ }^{3}$, \\ Carla Aparecida Soares Saraiva ${ }^{3}$, Antônio da Costa Pinheiro ${ }^{1}$, Vinícius de França Carvalho Fonsêca ${ }^{2,4}$, \\ Severino Guilherme Caetano Gonçalves dos Santos ${ }^{5}{ }^{\circ}$, Carla Giselly de Souza ${ }^{6}{ }^{\circ}$, Maria Elivânia Vieira Almeida ${ }^{2}$, \\ Tarsys Noan Silva Veríssimo ${ }^{2}$ and Larissa Kellen da Cunha Morais ${ }^{2}$
}

check for

updates

Citation: Santos, J.D.C.d.; Saraiva, E.P.; Gonzaga Neto, S.; Saraiva, C.A.S.; Pinheiro, A.d.C.; Fonsêca, V.d.F.C.; Santos, S.G.C.G.d.; Souza, C.G.d.; Almeida, M.E.V.; Veríssimo, T.N.S.; et al. Feeding Behavior of Lactating Dairy Cattle Fed Sorghum-Based Diets and Increasing Levels of Tannic Acid. Agriculture 2021, 11, 172. https:// doi.org/10.3390/agriculture11020172

Received: 27 November 2020 Accepted: 19 December 2020 Published: 20 February 2021

Publisher's Note: MDPI stays neutral with regard to jurisdictional claims in published maps and institutional affiliations.

Copyright: (C) 2021 by the authors Licensee MDPI, Basel, Switzerland. This article is an open access article distributed under the terms and conditions of the Creative Commons Attribution (CC BY) license (https:/ / creativecommons.org/licenses/by/ $4.0 /)$.
1 Animal Science Integrated PhD Program, Federal University of Paraiba (UFPB), Areia, PB 58397-000, Brazil; danrleyczootecnia@gmail.com (J.D.C.d.S.); antonio_costa02@hotmail.com (A.d.C.P.)

2 Research Group in Bioclimatology, Ethology and Animal Welfare (BioEt), Department of Animal Science, Federal University of Paraiba (UFPB), Areia, PB 58397-000, Brazil; vinicius_fonseca86@hotmail.com (V.d.F.C.F.); elivaniazootecnista@gmail.com (M.E.V.A.); verissimotns@hotmail.com (T.N.S.V.); larissakcm@gmail.com (L.K.d.C.M.)

3 Department of Animal Science, Federal University of Paraiba (UFPB), Areia, PB 58397-000, Brazil; sgonzaganeto@gmail.com (S.G.N.); carla@cca.ufpb.br (C.A.S.S.)

4 Innovations in Biometeorology Group, Department of Animal Science, São Paulo State University (UNESP), Jaboticabal, SP 14884-300, Brazil

5 National Institute of Semiarid (INSA), Campina Grande, PB 58434-700, Brazil; severino.santos@insa.gov.br

6 Faculty of Agricultural Sciences, Federal University of Grande Dourados (UFGD), Dourados, MS 79804-970, Brazil; carlaxlsouza@yahoo.com.br

* Correspondence: edilson@cca.ufpb.br; Tel.: +55-83-99608-4756

\begin{abstract}
Tannins have been used to trigger positive effects on ruminal metabolism and increase ruminant production efficiency, since they increase the supply of dietary protein in the small intestine. Increasing levels of tannic acid in a sorghum-based diet on the feeding behavior of five Holstein/Zebu crossbred lactating dairy cows was evaluated. They were subjected to a $5 \times 5$ Latin square experimental design, with fivelevels of tannin as dry matter (DM) in the diet $(0.46,1.30,2.60,3.90$, and $5.20 \%$ ). The levels of the tannic acid added were established based on the quantity of condensed tannin in high-tannin sorghum. Thus, diets 2, 3, 4 and 5 were supplemented with $1.5 \mathrm{~g}(13 \% \mathrm{DM})$, $79.5 \mathrm{~g}(2.6 \% \mathrm{DM}), 157.5 \mathrm{~g}$ (3.9\% DM), and $235.5 \mathrm{~g}$ (5.2\% DM) of tannic acid, totaling 0.078, 0.156, 0.234, and $0.321 \mathrm{~kg}$ of tannin/day, respectively. Feeding behavior variables included the following states and events: feeding, drinking, rumination, and inactivity; the frequency of visiting the feed and water troughs; and the occurrence of urination and defecation. Water was provided ad libitum, and its intake was measured during periods of behavioral data collection. The use of two tannin sources (hydrolysable and condensed) corresponding to the total level of 5.20\% (on a DM basis) in the diet of lactating dairy cattle does not affect the animals' health. Tannic acid can be included in the diet of lactating dairy cattle at a level of 3.93\% (on a DM basis) without inducing variation in the total time spent daily on feed intake. Dairy cows dilute the effects of dietary tannin (5.20\%) through greater fragmentation of food consumption in the hours following its supply (180 min). The astringent effects caused by tannin intake in lactating dairy cows are mitigated by increasing the daily water intake as the amount of tannin in the diet increases, starting at a level of $3.90 \%$ tannin (on a DM basis).
\end{abstract}

Keywords: behavior; nutrition; ruminant; tannin

\section{Introduction}

The use of tannin in ruminant nutrition is increasing, mainly due to its diverse positive effects in several aspects concerning physiology, metabolism, and animal performance. However, research results are quite controversial regarding the concentrations and sources used, which reinforces the need for further studies to elucidate these still evident gaps. 
According to Haslam and Lilley [1], tannins represent secondary compounds of plants and are present in many species that are commonly consumed by ruminants. They are generally defined as water-soluble polymeric phenolics that precipitate proteins, and are classified into hydrolysable and condensed tannins.

The effects of tannin can start even before its action at deeper levels in the organisms; that is, once present in the animal's mouth it can cause changes in its feeding behavior; the astringency caused by the consumption of these phenolic compounds exerts short-term effects in an animal's mouth that can be felt immediately upon ingestion [2,3]. Thus, the selection of the food to compose an animal's diet depends significantly on its acceptability and its post-ingestion effects.

Tannins are usually associated with decreased palatability and, consequently, with an influence on the time spent eating. However, moderate amounts of some types of tannins ingested by ruminants have the potential to improve productivity and dietary protein utilization efficiency in the small intestine, to reduce the negative impact of gastrointestinal parasites, and to reduce urea excretion via urine and methane emission into the environment [4-6].

Low to moderate concentrations $(2-4 \%)$ of condensed tannins in ruminant diets are considered to increase the post-ruminal flow of non-ammonia nitrogen $(\mathrm{N})$ due to theability to form reversible complexes with feed proteins and thereby protect from rumen degradation and enhance the animals' protein supply [7]. Due to the connection between tannins and dietary protein and a reduction in the activity of a large number of ruminal microorganisms, the rate of amino acid absorption in the intestine increases, which improves nitrogen utilization by ruminants [8]. Thus, the presence of tannins in the diet of ruminants may be associated with improvements in animal growth and productivity and, consequently, with a minimization of environmental damage [9] through a decrease in nitrogen excretion.

The negative effects most cited in literature for tannins are associated with a decreased digestibility of dietary protein and fiber by ruminal microorganisms and a decreased voluntary intake. Small amounts of added dietary tannin have shown little influence on the feeding behavior of cattle, but high tannin concentrations ( $>50 \mathrm{~g} / \mathrm{kg}$ dry matter (DM), significantly reduce voluntary intake [9], DM intake, and milk production in lactating dairy cows [10]. With these effects, different behavioral strategies to deal with tannin ingestion could depend on different amounts of tannin intake, the source of the tannin [11], and the type of tannin in the diet.

According to Landau et al. [12], the tannin offered by trees (Aspidospermaquebracho) in the diet of heifers decreased the feeding time. This effect occurred mainly through a reduction in the duration of meals instead of a decrease in the number of meals. However, the addition of tannin from Acacia mearnsii extracts to the diet of dairy cows did not affect forage intake or total dietary intake, which averaged 11.8 and $17.0 \mathrm{~kg} /$ day, respectively. For the concentrate, its intake tended to decrease among the treated animals [13].

Thus, the use of tannin in the diet of lactating cows has not yet been fully elucidated. Literature lacks information mainly on how the pattern of feeding behavior is modified by the type and concentration of tannin in the diet and how the animals adapt to the ingestion of these compounds, maintaining satisfactory levels of production. Therefore, the objectiveof this study was to evaluate the effect of different levels of dietary tannins on the feeding behavior of crossbred lactating dairy cattle.

\section{Materials and Methods}

All practices performed in the present study involving the use of animals were approved by the Institutional Animal Care of the Ethics Commission in Animal Use of the Biotechnological Centre of Federal University of Paraiba (CEUA/BIOTEC/UFPB) (protocol number 072/2016). 


\subsection{Animals, Management, and Experimental Design}

The study was conducted in the Cattle Production Unit of the Center for Agricultural Sciences of the Federal University of Paraíba (Universidade Federal da Paraíba-UFPB), Campus II, in the municipality of Areia, PB, Brazil. Areia city is located in the BrejoParaibano micro-region, at $6^{\circ} 57^{\prime} 42^{\prime \prime}$ South Latitude, $35^{\circ} 41^{\prime} 43^{\prime \prime}$ West Longitude and altitude of $575 \mathrm{~m}$. The average temperature varies between 18 and $29^{\circ} \mathrm{C}$, with minimal monthly fluctuations and an average annual rainfall of $1305 \mathrm{~mm}$.

Five primiparous crossbred cows (Holstein/Zebu), at approximately four years of age, at an average live weight of $420 \pm 30 \mathrm{~kg}$, at approximately 100 days of lactation, with average initial production of $18 \pm 4 \mathrm{~kg}$ /day were used. Before starting the experiment, the cows were dewormed and treated against ectoparasites with Ivermectin 3.5\%, and then subjected to the adaptation to the premises, experimental diets, and management for 10 days.

The experimental design used was a $5 \times 5$ Latin square with 5 treatments, evaluated in 5 periods of 20 days each, totaling 100 experimental days.

The treatments consisted of five sorghum-based diets, prepared with the inclusion of increasing levels of tannic acid $(0.00 \% ; 0.03 \% ; 1.33 \% ; 2.63 \%$, and $3.93 \%$ in DM) until the desired tannin content is reached $(0.46 \% ; 1.30 \% ; 2.60 \% ; 3.90 \%$, and $5.20 \%$ in DM). The inclusion levels of tannic acid were constituted based on the analysis of the amount of condensed tannin present in the low and moderate tannin sorghum, used in the experimental diets.

Diet 1 (control), contained the sorghum Ponta Negra BRS cultivar, in an attempt to offer as little tannin as possible. The other diets contained sorghum A9904 cultivar, which was the cultivar with the highest amount of tannin available. Sorghum cultivar BRS Ponta Negra presented $0.92 \%$ total condensed tannin in the DM by the methodology of Terril et al. [14]. Cultivating A9904 according to the HCL-Butanol methodology, [15] presented $2.55 \%$ of total condensed tannin in the DM. As forage, corn silage was offered to the animals.

Tannic acid $\left(\mathrm{C}_{76} \mathrm{H}_{52} \mathrm{O}_{46}\right)$ P.A. was purchased from Anidrol ${ }^{\circledR}$ laboratory products, Diadema-SP 09961-390, Brazil. A purified powder product was added to prepare the increasing tannin doses. Predetermined proportions of powdered tannic acid (based on the quantity of condensed tannin from sorghum A9904, 1.3, were added, continuously, to this same quantity, therefore, 2.6,3.9, and 5.2, to find the final total percentages) were mixed with the concentrate on the day before trough feeding. Thus, diets $2,3,4$, and 5 were supplemented with $1.5,79.5,157.5$, and $235.5 \mathrm{~g}$ of tannic acid, respectively, and provided an increase in the dietary total tannin percentage.

The experimental diets were formulated according to the nutritional requirements of lactating dairy cattle with a mean production of $18 \mathrm{~kg} /$ day, according to the National Research Council-NCR [16].The diets were supplied twice a day, at 6:00 a.m. (50\%) and 2:00 p.m. (50\%), immediately after milking, and allowed for an excess of approximately $5 \%$, with the orts collected every day. Water was provided ad libitum.

The experimental diets were offered at a forage:concentrate ratio of 64:36, and their components were presented separately in the feeding trough (forage on the right side and concentrate on the left side in both feeding troughs) in an attempt to ensure the total consumption of the tannic acid contained in the concentrate.

\subsection{Behavioural Measures}

Feeding behavior was observed continuously for $24 \mathrm{~h}$. The 1st and 2nd days were named Time I; the 9th and 10th, Time II; and the 17th and 19th days were named Time III, of each experimental period days, totaling $144 \mathrm{~h}$ of observations for each treatment per period.

Behavioral observations were performed in a direct, continuous, and focal animal sampling [17]. Twelve people conducted the observations and were divided into groups of three people who conducted $6 \mathrm{~h}$ shifts. All observers were subjected to a confidence test for the records of behavioral activities [18]. Focal animal evaluation was performed with the observers positioned within the facilities, so as not to interfere with animal behavior. 
The behavioral variables expressed as behavioral states were feeding, ruminating, resting, and water intake times; and those expressed as behavioral events were the frequency of visits to the feeding and the drinking troughs and the physiological variables of urination and defecation.

The feeding time was measured when the animals put their mouths inside the feeder, seized the food, and chewed, while the frequency of visits to the feeder was considered the number of times the animal sought the feeder and fed. Rumination time was regarded as the period of time in which the animals were not feeding but were chewing the feed bolus returned from the rumen, characterized by cyclic and repetitive mandibular movements. Inactivity time was the period during which the animals were not feeding or ruminating, including periods of rest (standing or lying down). Lastly, the time and frequency of water intake were, respectively, the duration of time spent at the drinking trough and the frequency of visits to the drinking trough, further confirmed by water intake.

Based on the daily time spent eating, the total percentage of daily time spent by the animals for forage and concentrate intake during the day was calculated. In addition, the time spent by the animals to consume the concentrate throughout the day and during the first 3 hafter the feed was offered was quantified.

\subsection{Measurement of Water Intake}

Water was provided ad libitum individually in plastic $100 \mathrm{~L}$ drinking troughs suitable for livestock. Water intake was recorded twice daily (at 6:00 a.m. and 1:00 p.m.) during the days of behavioral assessment.

A drinker with the same specifications was placed in another stall without animals, to quantify the rate of water evaporation/day. Therefore, when calculating the water consumption of the animals, the quantities of water offered, evaporated, and remaining water in the trough, the following equation was considered:

$$
\mathrm{WI}_{\text {daily }}=\mathrm{AWO}-\mathrm{AEW}-\mathrm{RW},
$$

where $\mathrm{WI}_{\text {daily }}=$ daily water intake, $\mathrm{AWO}=$ amount of water offered, $\mathrm{AEW}=$ amount of water evaporated, and $\mathrm{RW}=$ amount of water remaining in the trough.

\subsection{Statistical Analysis}

Exploratory analyses were performed to verify the normality of the data distribution. For parametric analysis, the variables were subjected to an analysis of variance by the "GENMOD" procedure, and the significant means were compared by the Tukey test with a $5 \%$ confidence level, following the respective mathematical model:

$$
\mathrm{Y}_{\mathrm{ijkl}}=\mu+\mathrm{F}_{\mathrm{i}}+\mathrm{T}_{\mathrm{k}}+(\mathrm{FT})_{\mathrm{ik}}+\mathrm{e}_{\mathrm{ijklm}},
$$

where $Y_{i j k l}$-observed variable; $\mu$-general average; $F_{i}$-feeding effect; $T_{k}$-time effect; $(\mathrm{FT})_{\mathrm{ik}}$ - effect of feeding vc time interaction; $\mathrm{e}_{\mathrm{ijk} k \mathrm{~m}}$-residue.

Orthogonal polynomial contrasts were used to determine the linear and quadratic effects of increasing the tannin ratio. All analyses were performed using the SAS [19] statistical software.

\section{Results}

\subsection{Effect of the Tannin Content on Feeding Behaviour}

The feeding, rumination, inactivity, and water intake times did not differ $(p>0.05)$ by the dietary tannins levels used, at any time during the study periods. Similarly, there was no interaction effect between diet and study Times on behavioral variables (Table 1).

The frequency of defecation and urination did not vary with the level of dietary tannin and different times during the study periods, as well as the frequency of visits to the drinking trough $(p>0.05)$. The frequency of visits to the feeding trough was affected $(p<0.05)$ by the sources of variation (level of dietary tannin $\times$ different times during the study periods) (Table 2). 
Table 1. A total daily time of feeding, rumination, inactivity, and water intake by lactating dairy cows as a function of dietary tannin levels, in three times of the study periods.

\begin{tabular}{|c|c|c|c|c|c|c|}
\hline \multirow{2}{*}{ Behavioral Variable } & \multicolumn{3}{|c|}{ Times } & \multicolumn{3}{|c|}{$p$ Value } \\
\hline & I & II & III & Diets & Times & Diets $\times$ Times \\
\hline Diets/Total tannin (\%) & \multicolumn{3}{|c|}{ Feeding $(\% / \mathrm{h})$} & & & \\
\hline Diet $1-0.46$ & 16.29 & 16.32 & 15.64 & \multirow{5}{*}{0.206} & \multirow{5}{*}{0.378} & \multirow{5}{*}{0.150} \\
\hline Diet $2-1.30$ & 19.98 & 17.79 & 16.04 & & & \\
\hline Diet 3-2.60 & 18.45 & 17.53 & 17.90 & & & \\
\hline Diet $4-3.90$ & 18.14 & 14.47 & 16.58 & & & \\
\hline Diet $5-5.20$ & 15.82 & 17.13 & 18.99 & & & \\
\hline \multicolumn{7}{|c|}{ Rumination $(\% / \mathrm{h})$} \\
\hline Diet $1-0.46$ & 38.96 & 35.27 & 36.41 & \multirow{5}{*}{0.133} & \multirow{5}{*}{0.568} & \multirow{5}{*}{0.120} \\
\hline Diet $2-1.30$ & 35.85 & 36.51 & 38.83 & & & \\
\hline Diet 3-2.60 & 36.91 & 39.51 & 40.57 & & & \\
\hline Diet $4-3.90$ & 34.96 & 37.94 & 35.36 & & & \\
\hline Diet $5-5.20$ & 37.83 & 40.41 & 36.86 & & & \\
\hline \multicolumn{7}{|c|}{ Inactivity $(\% / \mathrm{h})$} \\
\hline Diet $1-0.46$ & 44.17 & 47.91 & 47.38 & \multirow{5}{*}{0.057} & \multirow{5}{*}{0.999} & \multirow{5}{*}{0.726} \\
\hline Diet $2-1.30$ & 43.50 & 44.71 & 44.58 & & & \\
\hline Diet 3-2.60 & 44.03 & 42.47 & 41.02 & & & \\
\hline Diet $4-3.90$ & 46.17 & 47.09 & 47.38 & & & \\
\hline Diet 5-5.20 & 45.86 & 41.78 & 43.54 & & & \\
\hline \multicolumn{7}{|c|}{ Water intake $(\% / \mathrm{h})$} \\
\hline Diet $1-0.46$ & 0.57 & 0.72 & 0.57 & \multirow{5}{*}{0.915} & \multirow{5}{*}{0.865} & \multirow{5}{*}{0.962} \\
\hline Diet $2-1.30$ & 0.67 & 0.99 & 0.55 & & & \\
\hline Diet 3-2.60 & 0.61 & 0.49 & 0.58 & & & \\
\hline Diet $4-3.90$ & 0.72 & 0.50 & 0.67 & & & \\
\hline Diet $5-5.20$ & 0.50 & 0.68 & 0.61 & & & \\
\hline
\end{tabular}

Table 2. Frequency of defecation, urination, and visits to the feeding trough and drinking trough by lactating dairy cows as a function of dietary tannin levels, in three times of the study periods.

\begin{tabular}{|c|c|c|c|c|c|c|}
\hline \multirow{2}{*}{ Behavioral Variable } & \multicolumn{3}{|c|}{ Times } & \multicolumn{3}{|c|}{$p$ Value } \\
\hline & I & II & III & Diets & Times & Diets $\times$ Times \\
\hline Diets/Total tannin (\%) & \multicolumn{3}{|c|}{ Defecation $(n)$} & & & \\
\hline Diet $1-0.46$ & 13.5 & 14.0 & 13.1 & \multirow{5}{*}{0.595} & \multirow{5}{*}{0.537} & \multirow{5}{*}{0.770} \\
\hline Diet $2-1.30$ & 14.4 & 13.3 & 15.5 & & & \\
\hline Diet 3-2.60 & 13.7 & 13.7 & 15.9 & & & \\
\hline Diet $4-3.90$ & 12.5 & 14.2 & 12.6 & & & \\
\hline Diet $5-5.20$ & 13.5 & 13.6 & 14.8 & & & \\
\hline Linear & \multirow{2}{*}{\multicolumn{3}{|c|}{${ }^{1} \mathrm{~ns}$}} & & & \\
\hline Quadratic & & & & & & \\
\hline \multicolumn{7}{|c|}{ Urination $(n)$} \\
\hline Diet $1-0.46$ & 7.2 & 7.7 & 7.1 & \multirow{5}{*}{0.998} & \multirow{5}{*}{0.880} & \multirow{5}{*}{0.319} \\
\hline Diet $2-1.30$ & 7.9 & 5.9 & 8.8 & & & \\
\hline Diet 3-2.60 & 7.4 & 7.7 & 7.2 & & & \\
\hline Diet $4-3.90$ & 6.9 & 8.7 & 7.0 & & & \\
\hline Diet $5-5.20$ & 6.8 & 7.6 & 7.4 & & & \\
\hline Linear & \multirow{2}{*}{\multicolumn{3}{|c|}{$\begin{array}{l}{ }^{1} \mathrm{~ns} \\
{ }^{1} \mathrm{~ns}\end{array}$}} & & & \\
\hline Quadratic & & & & & & \\
\hline \multicolumn{7}{|c|}{ Feeding trough $(n)$} \\
\hline Diet $1-0.46$ & $10.0 \mathrm{bC}$ & $14.9 \mathrm{aA}$ & $12.5 \mathrm{abB}$ & \multirow{5}{*}{0.172} & \multirow{5}{*}{0.064} & \multirow{5}{*}{$<0.001$} \\
\hline Diet $2-1.30$ & $21.2 \mathrm{aA}$ & $14.2 \mathrm{bA}$ & $8.3 \mathrm{cC}$ & & & \\
\hline Diet $3-2.60$ & $13.2 \mathrm{aB}$ & $16.0 \mathrm{aA}$ & $10.1 \mathrm{bBC}$ & & & \\
\hline Diet $4-3.90$ & $12.8 \mathrm{bBC}$ & $9.5 \mathrm{cB}$ & $16.9 \mathrm{aA}$ & & & \\
\hline Diet $5-5.20$ & $11.2 \mathrm{BC}$ & $10.9 \mathrm{~B}$ & $11.9 \mathrm{~B}$ & & & \\
\hline Linear & & ${ }^{1} \mathrm{~ns}$ & & & & \\
\hline Quadratic & & ${ }^{1} \mathrm{~ns}$ & & & & \\
\hline
\end{tabular}


Table 2. Cont.

\begin{tabular}{|c|c|c|c|c|c|c|}
\hline \multirow{2}{*}{ Behavioral Variable } & \multicolumn{3}{|c|}{ Times } & \multicolumn{3}{|c|}{$p$ Value } \\
\hline & $\mathbf{I}$ & II & III & Diets & Times & Diets $\times$ Times \\
\hline \multicolumn{7}{|c|}{ Drinking trough $(n)$} \\
\hline Diet $1-0.46$ & 7.9 & 9.0 & 7.6 & & & \\
\hline Diet $2-1.30$ & 9.3 & 8.9 & 7.8 & & & \\
\hline Diet $3-2.60$ & 7.5 & 6.4 & 6.8 & 0.163 & 0.547 & 0.230 \\
\hline Diet $4-3.90$ & 9.6 & 6.4 & 8.7 & & & \\
\hline Diet $5-5.20$ & 7.5 & 8.9 & 7.9 & & & \\
\hline Linear & & ${ }^{1} \mathrm{~ns}$ & & & & \\
\hline Quadratic & & ${ }^{1} \mathrm{~ns}$ & & & & \\
\hline
\end{tabular}

Means followed by different lowercase letters $(a, b$, and $c)$ in rows and different uppercase letters $(A, B$, and $C)$ in columns differ by the Tukey test at the $5 \%$ probability level. ${ }^{1}$ Not significant (ns).

Diet $2(1.30 \%$ of tannin) promoted an increased $(p<0.05)$ frequency of visits to the feeding trough at Time I in comparison with Diet 3 (2.60\% of tannin), which did not differ $(p>0.05)$ from Diet 4 (3.90\% of tannin) and Diet 5 (5.20\% of tannin) treatments. The animals under the control diet $(0.46 \%$ tannin) showed relatively few visits to the feeding trough at Time I (Table 2).

At Time II, the $2.60 \%$ tannin treatment promoted a significantly greater frequency of visits to the feeding trough compared with those of the 3.90 and $5.20 \%$ treatments; however, this higher frequency of the $2.60 \%$ treatment did not differ $(p>0.05)$ from those shown by the $0.46 \%$ and $1.30 \%$ treatments (Table 2). At Time III, the animals on the $3.90 \%$ tannin diet showed a greater frequency of visits to the feeding trough $(p<0.05)$ compared with those on the $2.60 \%$ diet, which did not differ $(p>0.05)$ from the control or the $5.20 \%$ tannin diet. Compared with the other diets, the $1.30 \%$ tannin diet promoted a lower frequency $(p<0.05)$ of visits to the feeding trough at Time III (Table 1$)$.

For the $1.30 \%$ tannin diet, the frequency of animal visits to the feeding trough was higher at Time I of the different periods of the study $(p<0.05)$, decreasing in the other two Times (Time II and Time III). The animals in the $2.60 \%$ treatment showed a higher frequency of visits to the feeding trough at Time I and II compared to Time III $(p<0.05$; Table 2).

A higher frequency $(p<0.05)$ of visits to the feeding trough was observed for the $3.90 \%$ tannin treatment at Time III compared to Time I and II of the different periods of the study. For the $5.20 \%$ treatment, no change $(p>0.05)$ in the frequency of visits to the feeding trough occurred among the Times of the different periods of the study (Table 2).

The daily duration of forage and concentrate intake did not vary with the level of dietary tannin and different times during the study periods $(p>0.05)$. However, an effect $(p<0.05)$ of the sources of variation (dietary tannin level $\mathrm{x}$ at the time of study periods) occurred for the time spent daily on the intake of forage and concentrate (Table 3).

The $1.30 \%$ tannin treatment showed a decreased $(p<0.05)$ forage intake time at Time II of the study periods (73.63\%). This intake time was soon reestablished at Time III ( $p>0.05)$ and was similar to the percentage of time spent on forage intake at the Time I (86.67 and $84.51 \%$, respectively). The other treatments did not show variation among the Times of study periods for the time spent daily on forage intake (Table 3).

At Time I, a continuous increase in the time spent by the animals consuming the concentrate occurred because of the increased level of dietary tannin, but only the $5.20 \%$ tannin treatment showed a significantly longer $(p<0.05)$ time than the control treatment (Table 3). For Time II, the $1.30 \%$ tannin treatment was associated with a longer $(p<0.05)$ time for concentrate intake compared with the other treatments, which did not vary among themselves $(p>0.05)$. At Time III, no variation $(p>0.05)$ existed among the tannin treatments regarding the time spent daily on concentrate intake. The variation in the time spent daily for forage intake reflected that spent for concentrate intake but showed 
an inverse relationship. The animals on diets with $1.30 \%$ tannin spent a relatively long $(p<0.05)$ time for concentrate intake at Time II $(26.37 \%)$, with this time decreasing at Time III. The other diets showed no change $(p>0.05)$ in the daily time for concentrate intake among the times of study periods (Table 3 ).

Table 3. Percentage of time spent on a daily intake of forage and concentrate by lactating dairy cows as a function of dietary tannin levels, in three times of the study periods.

\begin{tabular}{|c|c|c|c|c|c|c|}
\hline \multirow{2}{*}{ Behavioral Variable } & \multicolumn{3}{|c|}{ Times } & \multicolumn{3}{|c|}{$p$ Value } \\
\hline & I & II & III & Diets & Times & Diets $\times$ Times \\
\hline Diets/Total tannin (\%) & \multicolumn{3}{|c|}{ Forage $(\% / \mathrm{h})$} & & & \\
\hline Diet $1-0.46$ & 87.80 & $84.96 \mathrm{~A}$ & 83.97 & \multirow{5}{*}{0.333} & \multirow{5}{*}{0.638} & \multirow{5}{*}{0.002} \\
\hline Diet $2-1.30$ & $86.67 \mathrm{a}$ & $73.63 \mathrm{bB}$ & $84.51 \mathrm{a}$ & & & \\
\hline Diet $3-2.60$ & 84.08 & $85.07 \mathrm{~A}$ & 80.69 & & & \\
\hline Diet $4-3.90$ & 82.58 & $86.73 \mathrm{~A}$ & 85.47 & & & \\
\hline Diet $5-5.20$ & 81.79 & $86.58 \mathrm{~A}$ & 81.07 & & & \\
\hline Linear & \multicolumn{3}{|c|}{${ }^{1} \mathrm{~ns}$} & & & \\
\hline Quadratic & \multicolumn{3}{|c|}{${ }^{1} \mathrm{~ns}$} & & & \\
\hline \multicolumn{7}{|c|}{ Concentrate $(\% / \mathrm{h})$} \\
\hline Diet $1-0.46$ & $12.20 \mathrm{~B}$ & $15.04 \mathrm{~B}$ & 16.03 & \multirow{5}{*}{0.285} & \multirow{5}{*}{0.601} & \multirow{5}{*}{0.005} \\
\hline Diet $2-1.30$ & $13.33 \mathrm{bAB}$ & $26.37 \mathrm{aA}$ & $15.49 \mathrm{~b}$ & & & \\
\hline Diet 3-2.60 & $15.92 \mathrm{AB}$ & $14.93 \mathrm{~B}$ & 19.31 & & & \\
\hline Diet $4-3.90$ & $17.42 \mathrm{AB}$ & $13.27 \mathrm{~B}$ & 14.53 & & & \\
\hline Diet $5-5.20$ & $18.21 \mathrm{~A}$ & $13.42 \mathrm{~B}$ & 18.93 & & & \\
\hline Linear & & ${ }^{1} \mathrm{~ns}$ & & & & \\
\hline Quadratic & & ${ }^{1} \mathrm{~ns}$ & & & & \\
\hline
\end{tabular}

Means followed by different lowercase letters $(a, b$, and $c)$ in rows and different uppercase letters $(A, B$, and $C$ ) in columns differ by the Tukey test at the $5 \%$ probability level. ${ }^{1}$ Not significant (ns).

\subsection{Daily Variations in Feeding Behavior}

The animals spent more time on concentrate intake during the first $60 \mathrm{~min}$ period compared with the second and third 60 min periods after the feed offer on all fivediets (Figure 1). By the second $60 \mathrm{~min}$ period (ending at $120 \mathrm{~min}$ following the feed offer), the animals in the $5.20 \%$ treatment showed an increased concentrate intake time compared with that shown by the other treatments. By the third $60 \mathrm{~min}$ period (ending at $180 \mathrm{~min}$ following the feed offer), no variation in concentrate intake time occurred among the treatments (Figure 1).

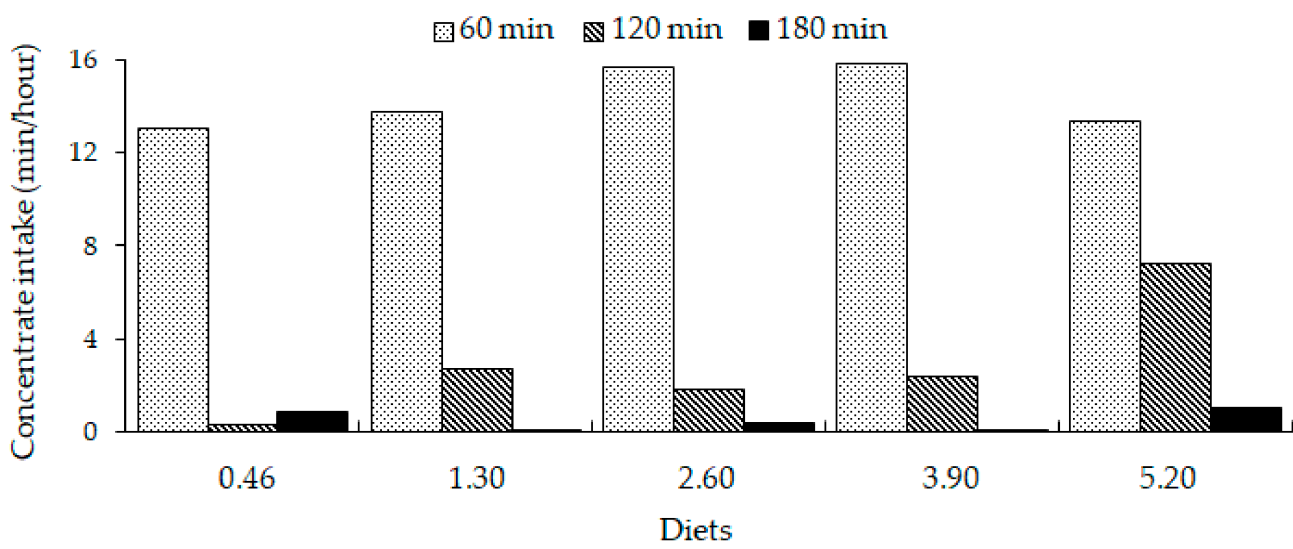

Figure 1. Time spent for concentrate intake by lactating dairy cows during each of the first $3 \mathrm{~h}$ (that is, the 1-h intervals ending 60,120 , and $180 \mathrm{~min}$ ) after the offer of feed. 
By analyzing the concentrate intake time throughout the day, an increased intake was observed for both treatments at the Times of study periods in the first hours after the diet was offered (Figure 2). However, at Time I and III, more time was spent through small peaks of concentrate intake during the day for the $5.20 \%$ treatment. No variation in the time of the concentrate intake occurred among the other treatments.
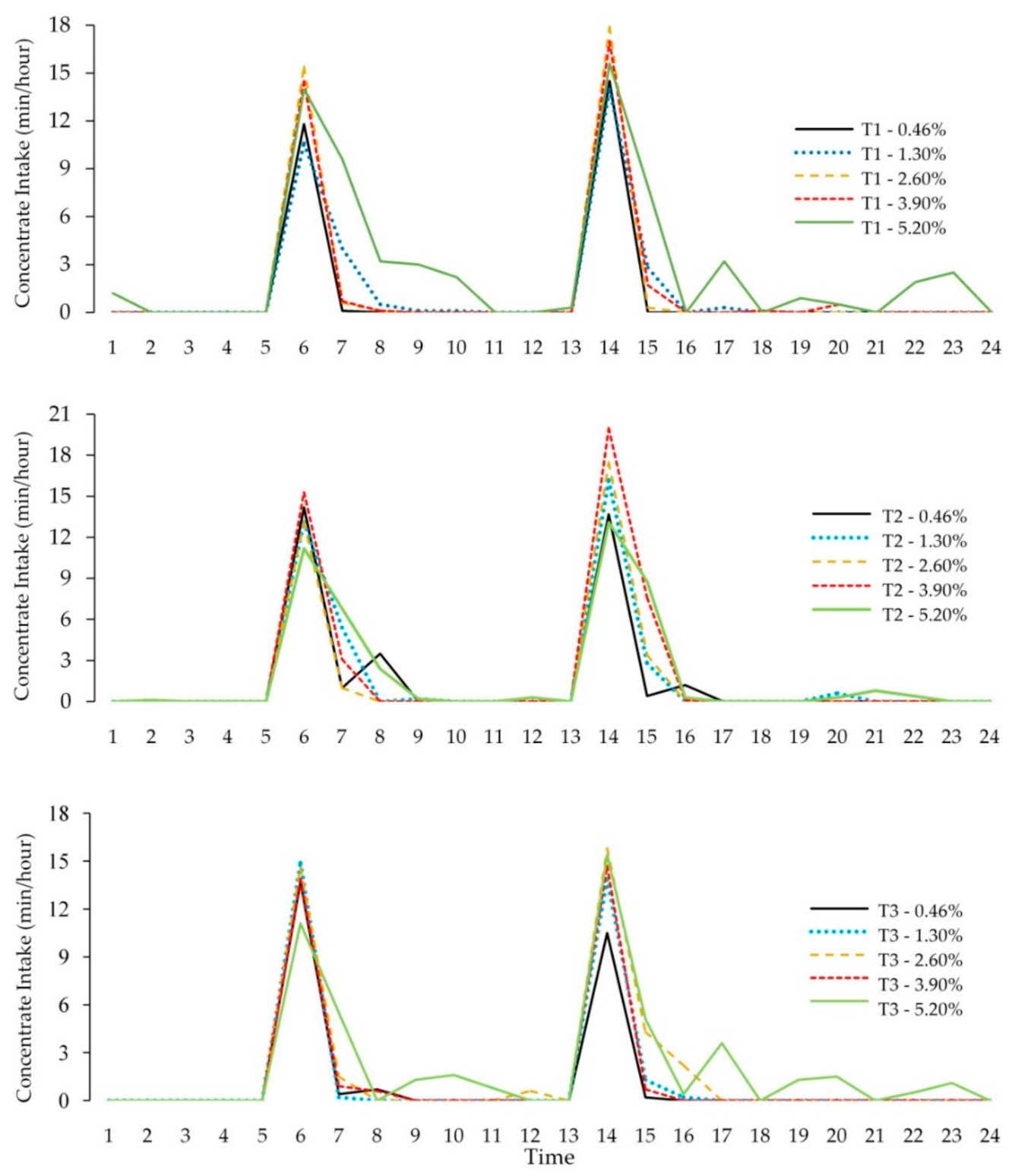

Figure 2. Daily time of concentrate intake at three different Times (T1, T2, and T3) in the experimental periods by lactating dairy cows fed diets containing different tannin levels.

\subsection{Effect of Tannin Content on Water Intake}

Water intake varied $(p<0.05)$ with the amount of dietary tannin. Animals consuming diets with $1.30 \%$ and $2.60 \%$ tannin showed relatively low water intakes (40.94 and $41.34 \mathrm{~L}$, respectively).

Higher water intake was observed for the $5.20 \%$ tannin diets ( $44.97 \mathrm{~L}$ ), whereas the diets containing $0.46 \%$ and $3.90 \%$ tannin showed no variation compared with the other diets (Figure 3). 


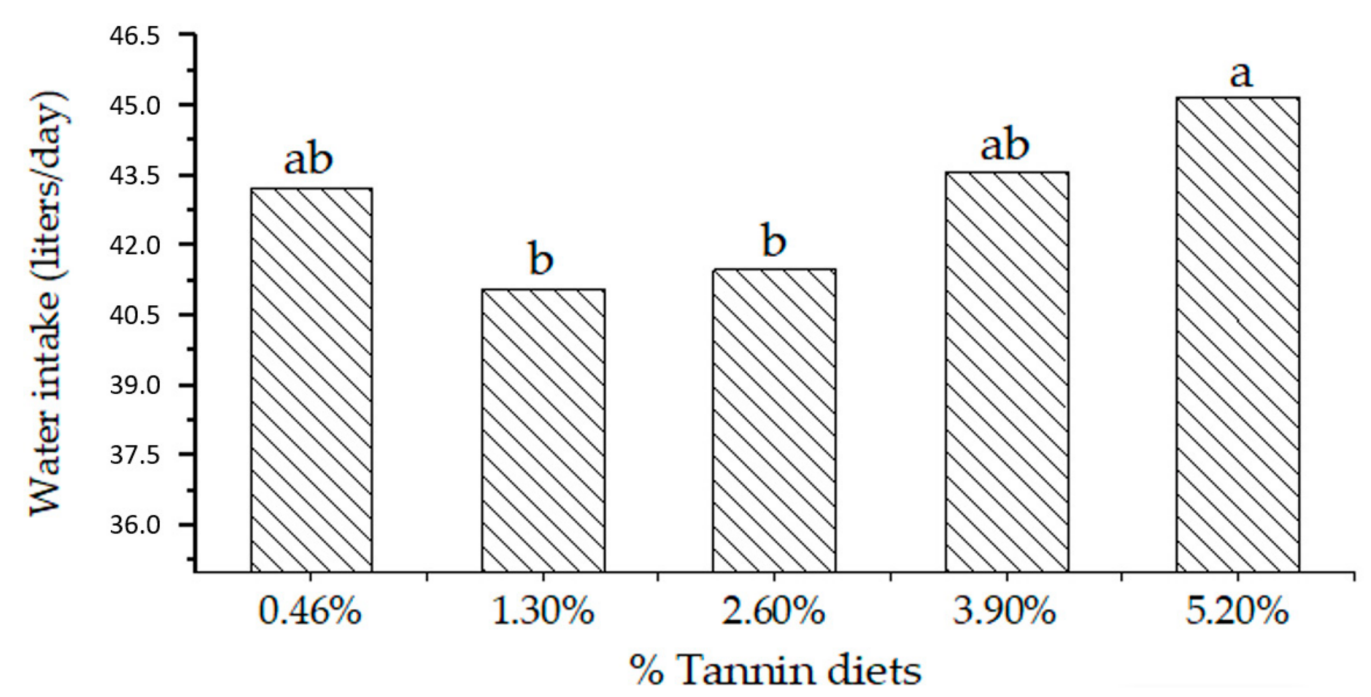

Figure 3. Daily water intake of lactating dairy cows fed dietary diets containing various tannin levels. Different lowercase letters $(a, b)$ indicate differences among tannin diets (axis: $X$ ) according to the Tukey test at the $5 \%$ probability level.

\section{Discussion}

The results of the present study showed that no variation existed in the total daily feed intake of dairy cows based on the tannin levels measured in their diets. Most likely, the lack of influence may relate to the moderate tannin addition to the diet, which was insufficient to affect the amount of time the animals spent feeding. Moreover, the nutritionally balanced composition of the experimental diets, which varied only in the amount of tannin present, may have contributed to the lack of variation in the feeding behavior variables.

Waghorn andShelton [20] reported that the daily tannin amount considered to be optimal when ingested with forage seems to be from $2 \%$ to $4 \%$ of the DM intake. Smaller amounts appear to have little or no benefit, while larger amounts may exert a toxic effect, although the effect depends on the type of tannin ingested.

To deal with the intake of tannins, ruminant animals establish different behavioral strategies that are associated with different tannin levels and sources in the diet. These factors may modulate the behavioral responses triggered by the ingestion of tannins in the short term (astringent effect), medium-term (post-feeding effects), and long term (aversive behavior) [11].

Landau et al. [12] did not observe changes in the feed intake of lactating dairy cows upon the daily addition of up to $500 \mathrm{~g}$ of tannin to the diet. However, when the daily tannin additions exceeded $500 \mathrm{~g}$, a 33\% decrease occurred in the feed intake, which was restored to normal levels when the tannin levels were reduced to their original levels.

The presence of moderate levels of tannin in the rumen may be beneficial to animals because tannin may protect dietary protein against degradation by ruminal microorganisms, thus increasing the flow of dietary protein available for absorption in the small intestine [21]. Another beneficial effect associated with tannin intake is the reduction of ruminal methane emission into the environment [2]. Lower amounts of methane emissions by goats were reported by Puchalaet al. [22] from goats fed with Lespedeza cuneata compared to grass (with tannin contents of $17.7 \%$ and $0.5 \%$ on a DM basis, respectively).

Diets containing condensed tannins from Lotus corniculatus at levels of $25.9 \mathrm{~g} / \mathrm{kg}$ of DM resulted in lower methane emission per kilogram of DM ingested by cattle [23]. In addition to reducing greenhouse gas emissions, these reductions in methane emissions may benefit animal production because less feed energy is lost by ruminant animals during the digestion process.

The $1.30 \%$ tannin diet exhibited interaction between the various sources (tannin treatment $\times$ times of study periods) on the frequency of visits to the feeding trough, 
with higher frequencies observed at Time I and a linear decrease that continued until Time III (Table 1). This pattern shows that these animals were adapting to the dietary tannin presence.

Although the feeding time did not vary significantly among the treatments, this variable was relatively high for the $1.30 \%$ and $2.60 \%$ treatments at Time I (Table 2); additionally, a relatively long time was spent in forage intake (Table 3), which may have resulted in the higher number of visits to the feeding trough for the $1.30 \%$ and $2.60 \%$ treatments at Time I. Therefore, the results did not clarify whether the animals were able to understand the influence of tannin on feeding because the highest frequency of visits to the feeding trough for the $3.90 \%$ treatment occurred at Time III, whereas no variation among the times of study periods occurred for the $5.20 \%$ treatment (Table 2). However, Landau et al. [12] reported that higher frequencies of contact with feed may be associated with more carefully selected sampling of the diet, especially in the presence of new feeds, which would be the case in this study because of the novel presence of tannin in the animal feeds.

Even though no statistically significant variation existed, the time spent on forage intake decreased as the level of tannin increased in diets at Time I. This decrease probably affected the concentrate intake time in a reverse pattern, that is, with more time spent on concentrate intake at Time I as the tannin level increased in the diet (Table 3).

Adjustments in the intake level and rate, the length, and the number of feeding periods, the total feeding time, and the interval between feeding periods are specific behaviors employed by animals to regulate the intake of secondary plant metabolites in time and/or space [24], especially when these compounds are new to their diets. These characteristics justify the greater variation observed in the animals fed with diets containing $1.30 \%$ tannin; these animals spent more time consuming the concentrate at Time II compared with the other treatments. However, no variation in the time spent on concentrate intake occurred among the times of study periods for the higher dietary tannin levels (Table 3).

The utilization of different levels of tannin in the diet of lactating dairy cows showed variation in the time of concentrate intake after feed offering among the times of the study periods. The difference in time spent on concentrate intake between the $5.20 \%$ treatment and the other treatments increased at Time I and III (Table 2).

The comparatively long time spent to consume diets with $5.20 \%$ tannin may be associated more with many daily meals than with long-lasting meals; that is, with many feed intake peaks spread over short intake times. Moreover, the animals in the $5.20 \%$ tannin treatment at $180 \mathrm{~min}$ after the feed was offered spent more time-consuming concentrate than the animals in the other tannin treatments (Figure 1).

The oral cavity plays an important role in the tannin intake process, as the site of both tannin detection and salivary proteins that defend against tannins [9]. Thus, an animal's need to avoid an astringent effect caused by the oral presence of tannin may possibly be associated with the relatively high number of meals throughout the day with comparatively short intake times. Furthermore, frequent salivation was observed in the cattle fed $5.20 \%$ tannin in the diet, supporting the notion that the interaction of tannins with salivary proteins and oral mucous membranes may be an important factor for reducingthe palatability of diets with increased amounts of tannin in a short time.

Adequate water intake is essential for the health and productivity of ruminants; however, certain factors, including the presence of tannins, may cause changes in water intake [6].

In the present study, an increase in the amount of water ingested was observed as the tannin level in the diet increased. The highest water intake was observed for the $5.20 \%$ tannin treatment (Figure 3) and probably occurred because of the astringent effects caused in the mouth by concurrent interactions of tannins and salivary proteins.

Astringency is a rough or dry feeling in the oral mucosa that usually slowly develops and dissipates [25]. One theory cited by Lamy et al. [9] suggests that the interaction of tannins and salivary proteins results in the formation of insoluble precipitates that stimulate oral mechanoreceptors, causing an increased sense of dryness. Thus, the animals attempted 
to circumvent and dilute the unpleasant effects caused by the dietary tanninoral presence by increasing the amount of water ingested.

\section{Conclusions}

The use of two tannin sources (hydrolysable and condensed) corresponding to the total level of $5.20 \%$ (on a DM basis) in the diet of lactating dairy cattle does not affect the animals health clinically, for the period of 100 days.

Tannic acid may be included in the diet of lactating dairy cattle at a level of 3.93\% (on a DM basis) without inducing variation in the total time spent daily on feed intake.

Dairy cows dilute the effects of dietary tannin $(5.20 \%)$ through greater fragmentation of food consumption in the hours following its supply (180 $\mathrm{min}$ ).

The astringent effects caused by the tannin intake by lactating dairy cows are mitigated by increasing the daily water intake as the tannin amount in the diet increases, starting at a tannin level of $3.90 \%$ (on a DM basis).

Author Contributions: Conceptualization, J.D.C.d.S., A.d.C.P., E.P.S., S.G.N., and C.A.S.S.; methodology, J.D.C.d.S., A.d.C.P., E.P.S., S.G.N., C.A.S.S., S.G.C.G.d.S., and V.d.F.C.F.; software, A.d.C.P., S.G.C.G.d.S., and C.G.d.S.; validation, J.D.C.d.S., S.G.C.G.d.S., and C.G.d.S.; formal analysis, J.D.C.d.S., A.d.C.P., S.G.N., S.G.C.G.d.S., and C.G.d.S.; investigation, A.d.C.P. and C.G.d.S.; resources, S.G.N and C.A.S.S.; data curation, A.d.C.P., M.E.V.A., T.N.S.V., J.D.C.d.S., and L.K.d.C.M.; writing—original draft preparation, A.d.C.P., E.P.S., S.G.N., and C.A.S.S.; writing-review and editing, A.d.C.P., E.P.S., and L.K.d.C.M.; visualization, A.d.C.P., E.P.S., S.G.N., C.A.S.S., and S.G.C.G.d.S.; supervision, E.P.S., S.G.N., and C.A.S.S.; project administration, E.P.S., S.G.N., and C.A.S.S.; funding acquisition, E.P.S. and S.G.N. All authors have read and agreed to the published version of the manuscript.

Funding: This research received no external funding.

Institutional Review Board Statement: The study was conducted according to the guidelines of the use of animals were approved by the Institutional Animal Care of the Ethics Commission in Animal Use of the Biotechnological Centre of Federal University of Paraiba (CEUA/BIOTEC/UFPB) (protocol number 072/2016).

Informed Consent Statement: Informed consent was obtained from all subjects involved in the study.

Data Availability Statement: The data that support the findings of this study are available upon request from the authors.

Acknowledgments: The authors wish to thank the Coordination for the Improvement of Higher Education Personnel (CAPES) and the authors also wish to thank the Research Group in Bioclimatology, Behavior and Animal Welfare (BIOET-UFPB).

Conflicts of Interest: The authors declare no conflict of interest.

\section{References}

1. Haslam, E.; Lilley, T.H.; Butler, L.G. Natural Astringency in Foodstuffs. Crit. Rev. Food Sci. Nutr. 1988, 27, 1-40. [CrossRef] [PubMed]

2. Makkar, H.P.S. Effects and fate of tannins in ruminant animals, adaptation to tannins, and strategies to overcome detrimental effects of feeding tannin-rich feeds. Small Rumin. Res. 2003, 49, 241-256. [CrossRef]

3. Waghorn, G. Beneficial and detrimental effects of dietary condensed tannins for sustainable sheep and goat production-Progress and challenges. Anim. Feed Sci. Technol. 2008, 147, 116-139. [CrossRef]

4. Mcnabb, W.C.; Waghorn, G.C.; Peters, J.S.; Barry, T.N. The effect of condensed tannins in Lotus pedunculatus on the solubilization and degradation of ribulose-1,5-bisphosphate carboxylase (EC 4.1.1.39; Rubisco) protein in the rumen and the sites of Rubisco digestion. Br. J. Nutr. 1996, 76, 535-549. [CrossRef] [PubMed]

5. Mueller-Harvey, I. Analysis of hydrolysable tannins. Anim. Feed Sci. Technol. 2001, 91, 3-20. [CrossRef]

6. Kronberg, S.L.; Schauer, C.S. Cattle and sheep develop preference for drinking water containing grape seed tannin. Animal 2013, 7, 1714-1720. [CrossRef]

7. Ahnert, S.; Dickhoefer, U.; Schulz, F.; Susenbeth, A. Influence of ruminal Quebracho tannin extract infusion on apparent nutrient digestibility, nitrogen balance, and urinary purine derivatives excretion in heifers. Livest. Sci. 2015, 177, 63-70. [CrossRef]

8. Makkar, H.P.S.; Blummel, M.; Becker, K. In Vitro Effects of and interactions between tannins and saponins and fate of tannins in the rumen. J. Sci. Food Agric. 1995, 69, 481-493. [CrossRef] 
9. Lamy, E.R.; Rawel, H.; Schweigert, F.J.; Capela e Silva, F.; Ferreira, A.; Costa, A.R.; Antunes, C.; Almeida, A.M.; Coelho, A.V.; Sales-Baptista, E. The effect of tannins on mediterranean ruminant ingestive behavior: The role of the oral cavity. Molecules 2011, 16, 2766-2784. [CrossRef]

10. Grainger, C.; Clarke, T.; Auldist, M.J.; Beauchemin, K.; McGinn, S.M.; Waghorn, G.C.; Eckard, R.J. Potential use of Acacia mearnsii condensed tannins to reduce methane emissions and nitrogen excretion from grazing dairy cows. Can. J. Anim. Sci. 2009, 84, 241-251. [CrossRef]

11. Molle, G.; Decandia, M.; Giovanetti, V.; Cabiddu, A.; Fois, N.; Sitzia, M. Responses to condensed tannins of flowering sulla (Hedysarumcoronarium L.) grazed by dairy sheep-Part 1: Effects on feeding behaviour, intake, diet digestibility and performance. Livest. Sci. 2009, 123, 138-146. [CrossRef]

12. Landau, S.; Silanikove, N.; Nitsan, Z.; Barkai, D.; Baram, H.; Provenza, F.D.; Perevolotsky, A. Short-term changes in eating patterns explain the effects of condensed tannins on feed intake in heifers. Appl. Anim. Behav. Sci. 2000, 69, 199-213. [CrossRef]

13. Alves, T.P.; Dall-Orsoletta, A.C.; Ribeiro-Filho, H.M.N. The effects of supplementing Acacia mearnsii tannin extract on dairy cow dry matter intake, milk production, and methane emission in a tropical pasture. Trop. Anim. Hearth Prod. 2017, 49, 1663-1668. [CrossRef] [PubMed]

14. Terril, T.H.; Rowan, A.M.; Douglas, G.B.; Barry, T.N. Determination of extractable and bound condensed tannin concentrations en forage plants, protein concentrate meals and cereal grains. J. Sci. Food Agric. 1992, 58, 321-329. [CrossRef]

15. Hagerman, A.E.; Butler, L.G. The specificity of proanthocyanidin-protein interactions. J. Biol. Chem. 1978, $256,4494-4497$.

16. National Research Council-NRC. Nutrient Requirements of the Dairy Cattle, 7th ed.; National Academy Press: Washington, DC, USA, 2001; 363p.

17. Martin, P.; Bateson, P.P.G. Measuring Behaviour: An Introductory Guide; Cambridge University Press: Cambridge, UK, 1993.

18. Fonsêca, V.F.C.; Saraiva, E.P.; PimentaFilho, E.C.; Furtado, D.A.; Mariz, T.M.A.; Silva, A.L.; Pinheiro, A.C. Influence of the climatic environment and duration of labor on the mother-offspring interaction in Morada Nova sheep. J. Anim. Sci. 2014, 92, 4123-4129. [CrossRef]

19. Statistical Analysis System Institute. Institute SAS/STAT Software, CD-ROOM; Statistical Analysis System Institute: Cary, NC, USA, 2010.

20. Waghorn, G.C.; Shelton, I.D. Effect of condensed tannins in Lotus pedunculatus on the nutritive value of ryegrass (Loliumperenne) fed to sheep. J. Agric. Sci. 1995, 125, 291-297. [CrossRef]

21. Min, B.R.; Barry, T.N.; Attwood, G.T.; McNabb, W.C. The effect of condensed tannins on the nutrition and health of ruminants fed fresh temperate forages: A review. Anim. Feed Sci. Technol. 2003, 106, 3-19. [CrossRef]

22. Puchala, R.; Min, B.R.; Goetsch, A.L.; Sahlu, T. The effect of a condensed tannin-containing forage on methane emission by goats. J. Anim. Sci. 2005, 83, 182-186. [CrossRef]

23. Woodward, S.L.; Waghorn, G.C.; Ulyatt, M.J.; Lassey, K.R. Early indications that feeding lotus will reduce methane emission from ruminants. N. Z. Soc. Anim. Prod. 2001, 61, 23-26.

24. Wiggins, N.L.; Mcarthur, C.; Boyle, R. Effects of two plant secondary metabolites, cineole and gallic acid, on nightly feeding patterns of the common brushtail possum. J. Chermical Ecol. 2003, 29, 1447-1464. [CrossRef] [PubMed]

25. Charlton, A.J.; Baxter, N.J.; Khan, M.L.; Moir, A.J.G.; Haslam, E.; Davies, A.P.; Williamson, M.P. Polyphenol/peptide binding and precipitation. J. Agric. Food Chem. 2002, 50, 1593-1601. [CrossRef] [PubMed] 